\title{
Contested national identities and weak state structures in Eurasia
}

\author{
Douglas Blum
}

Since their very inception, many of the Soviet successor states have been beset by ethnic violence, crime, trafficking - in arms, drugs and people terrorism, poverty, pollution and migration. ${ }^{1}$ Most have also faced deeper problems of legitimacy and ideological drift. To a significant extent these pathologies can be traced back to the delegitimisation of the entire Soviet world view, and the lack of any viable replacement. The existence of an institutional vacuum in the post-Soviet geopolitical space has both contributed to such problems and impeded their successful resolution. The post-Soviet states have been forced to rebuild themselves by establishing basic institutions of governance and administration. At the same time the massive legitimacy problems they face call for nation building, along either inclusive/ civic or exclusive/ethnic lines. Moreover, the post-Soviet transition is further complicated by its taking place in the context of globalisation and as such is marked by heightened economic interdependence, technology development and diffusion. A critical question, then, is how the state - understood here in traditional Weberian terms - responds to such challenges, and what the results are for its ability to achieve developmental and political goals while consolidating its own sovereignty.

The literature on globalisation and the state has generally addressed this question from a functional standpoint, considering the competence of centralised states to manage their responsibilities alone. Recent works in this vein have analysed the complex pattern of 'bargains', 'reconfigurations' and 'delegations' of sovereign authority as part of the state's response to globalisation. Less attention has been paid to the role of the state in promoting and defending the reproduction of a favoured national identity. This analytical indifference is puzzling, inasmuch as constructions of national identity are crucial for internal organisation and cohesion as well as for relations with external actors. Consequently the ongoing reproduction of identity is essential for maintaining group boundaries, or the 'self-Other nexus' in Fredrik 
Barth's terms. ${ }^{2}$ It is precisely the validity of these boundaries which is challenged under globalisation. Central to understanding the role of the state in post-Soviet Eurasian security is the recognition of its embeddedness in the overlapping and contradictory processes of cultural flux, state building and nation building.

This chapter investigates both the state in post-Soviet Eurasia as the primary site of institutionalisation and the state's concerted international action in the sphere of security. This investigation requires a major caveat: state-centric approaches to security impose analytical costs by obscuring substate and transnational actors and processes. In particular, state-centric conceptualisations are inadequate for grasping fully the decentralised aspects of control and organisation, because they overlook the social and discursive dimensions of these processes. ${ }^{3}$ While this approach is limited in theoretical depth and analytical scope, it is useful for the specific purpose of highlighting the state in its traditional Weberian form, as a uniquely privileged, central, bureaucratic agent driving regional political dynamics and (potentially) managing shared security dilemmas. ${ }^{4}$

It has already become well-accepted to note that nations are, as Benedict Anderson famously argued, 'imagined communities'. ${ }^{5}$ Not only do its members have to imagine their essential commonality with others, but the characteristics and boundaries of the group must be discursively created. Thus while the term 'nation' implies the existence of some group as a preexisting referent, the group cannot be understood as having a primordial solidarity based on intrinsic characteristics. Rather, national identity consists of the ostensibly shared characteristics which are constructed as being representative of the nation. ${ }^{6}$ National identity is rather an intersubjective fiction, because identity formation is not an objective fact based on some manifest material foundation. Thus, its ontological standing is unavoidably flimsy. This in turn makes it essential for national identity to be socially reproduced by its holders.

This 'reproduction' of national identity takes place through an ongoing social discourse which centers on two key markers: historical constitution and normative qualities. The first marker includes claims about who belongs to the group or on what objective social basis the nation coheres; that is, particular ethnic versus all-inclusive civic identity as the basis of citizenship - membership may be defined in terms of specific markers such as language or religion which are more inclusive than ethnicity. Such criteria are more restrictive than a civic identity, which would apply to anyone born within the geographic boundaries of the state. However it is defined, national identity competes with more parochial criteria for membership, such as region, clan or tribe. The obverse of membership inclusion is the delineation of difference and the construction of Others, whether as friends, enemies, or specific value-neutral outsiders. ${ }^{7}$

The second, normative marker concerns the fundamental social values of 
the group as a whole. Such categorisations of identity go beyond the 'who' of membership to include the 'how' and 'why' of political life: honour, role or purpose, power and so forth. Whether or not such values are actually achieved is of course less important than the shared sense of meaning they impart and the social cohesion this fosters. Indeed, broad social internalisation of officially articulated national identity is crucial for the state's legitimacy, and thus for its exercise of authority and its ability to mobilise willing compliance. ${ }^{8}$ It is perhaps most accurate to say that national identity constrains and at the same time enables government action, thus helping to shape the ultimate trajectory of state building and international conduct. ${ }^{9}$ This process of national identity formation and active reproduction is clearly evident in the post-Soviet Eurasian states.

\section{Nation building in Eurasia: the fusion of civic and ethnic identities}

By 1991 the Soviet practice of ethnicising politics (and promoting ethnic identification along historical-cultural lines) had become deeply entrenched. Thus despite their largely fictitious origins in Stalin's nationalities policy of divide and rule, these constructions provided one important basis for the separatist unrest that brought down the Soviet Union, an irony which has not gone unremarked. ${ }^{10}$ Post-Soviet nation building has also continued the practice of officially prescribed historiography. Scholars and cultural elites have dutifully laboured to produce 'homeland myths', as well as myths of ancient origin, glorious descent and intrinsic national character. ${ }^{11}$ For the most part ethnic, not religious, identities have been especially salient and highly politicised, leading some observers to refer to the 'ethnification of religion' in former Soviet Eurasia. Inasmuch as religion provides an important source of cultural solidarity, its expression has been officially manipulated and adapted to current social and political needs. ${ }^{12}$

At the same time a curious dualism is evident in the policies of the postSoviet states. Officially, exclusivist ethnic nationalism is rejected by all (with the partial exception of Armenia); instead tolerance is espoused and the dangers of ethnic extremism are repeatedly stressed in multinational states such as Azerbaijan, Kazakhstan and Russia. Yet in practice, in all of the Eurasian countries except Russia, national identity projects have been pursued predominantly in ethnic terms. ${ }^{13}$ For example in Kazakhstan and Azerbaijan, the titular nationality has accrued substantial advantages in political representation and cultural rights, but is tempered somewhat by the official self-image of multinationalism. This very ambivalence, as well as the overriding prominence of ethnic nationalist constructs, comes into play in the choice of foreign policies and institutional affiliations. While ethnic attachments are central to ongoing notions of national purpose, and for designation of Others, civic and even universalist ideas come to the fore as a product of heightened international interaction. 


\section{Eurasian identity narratives}

What are the nature and significance of prevailing national identities in post-Soviet Eurasia? The evolution of national identity has produced three broad categories of states: those with a well-consolidated national identity; those where national identity remains contested, but where key cleavages are not ethnic; and those where there is significant identity fragmentation along ethnic lines. What follows is a brief overview which delineates the key similarities and differences among the Eurasian states, particularly with regard to the relationship between national identity and foreign policy orientation.

The first group includes Armenia and, at least superficially, Turkmenistan; that is, states with well-consolidated national identities. Clearly at one end of the spectrum is Armenia, which has a nearly homogeneous population and a unified national identity based on common cultural symbols and an image of historical suffering. ${ }^{14}$ The war with Azerbaijan has led to a situation in which ethnic identity far outweighs any meaningful civic alternative. Along with Armenia, at least judging from surface appearances, it may be possible to include Turkmenistan in this category. Certainly the official national identity is pronounced, including an ethnicised self-representation replete with various Turkic and Islamic cultural symbols and inventions. ${ }^{15}$ However, the Niyazov regime is so closed and so highly authoritarian that it is impossible to gauge accurately whether the apparent consensus over national identity is real, and anecdotal reports suggest it may not be.

The second group to be distinguished consists of Russia, Moldova and Azerbaijan: the national identity discourse in each remains essentially contested, but the key identity cleavages are not drawn along ethnic lines. Chechnya, Transdniestria and Nagorno-Karabakh are obviously glaring exceptions to this rule, but they make up only a small part of each country's total geographic space and identity discourse.

Analysts have stressed the multiplicity of competing narratives within the Russian polity, ranging from liberal-westerniser to unreconstructed neoSoviet. ${ }^{16}$ Between 1991 and 2000, this welter of opposing voices prevented consolidation of an ideological basis for mobilisation. However, Vladimir Putin's emergence signals an effort to rebuild and strengthen the nationstate by invigorating a pragmatic statist discourse. While no definitive answer has emerged in the quest to define a unifying 'Russian idea', the mainstream debate has narrowed significantly as extreme right- and leftwing views have been marginalised.

One prominent theme involves the re-emergence of distancing from the West, along with an exceptionalist self-image as the embodiment of some transcendent truth or goodness, increasingly linked to Christian Orthodoxy. ${ }^{17}$ This is often connected with an image of Russia as essentially a Eurasian 'great power'. In contrast, an equally important tendency identi- 
fies Russia as fully European, and as such set apart from America with regard to culture and security concerns. ${ }^{18}$ Both narratives, however, share a predominantly geopolitical orientation to world politics. Another common feature is an insistence on maintaining preponderant influence in the "near abroad', which appears to reflect an extension of native geopolitical space in Russian national consciousness. ${ }^{19}$

Moldova has experienced a modern history of incorporation into the Russian empire and later annexation by the Soviet Union (with loss of territory to Ukraine). During perestroika a recrudescence of national identity took place, mainly through the rediscovery of Romanian roots. Since gaining independence, however, there has been a powerful resurgence of Moldovan identity, initially constructed along ethnic lines as Latin and historically Roman, including perhaps above all an assertion of non-Russian cultural particularity. This too changed, however, following the sharp reactions of the sizeable Gagauz and Ukrainian populations, resulting in the articulation of a civic Moldovan identity which has persisted alongside the ethnic variant. ${ }^{20}$ The ultimate willingness of Moldovans to allow Gagauz autonomy has resulted in a relatively stable domestic order, aside from the smouldering conflict in Transdniestria. ${ }^{21}$ Even here, as Stuart Kaufman has cogently argued, the conflict has been essentially elite-led, in contrast to Nagorno-Karabakh, where extensive and especially vicious ethnic violence has resulted in conflict being mass-led and self-perpetuating. ${ }^{22}$

Finally, Azerbaijan presents a somewhat more ambiguous picture. It boasts a well-established official national identity associated with claims of a unique heritage based on an improbable blend of Turkism, Zoroastrianism, moderate Islam, and its historical function as 'bridge' between Asia and Europe along the Silk Road. ${ }^{23}$ At the same time there remain strong local allegiances and ethnic distinctions, including submerged tensions between Azeris, Russians, and also Lezgins and Talysh (besides Armenians), as well as stubborn religious cleavages (roughly two thirds of the Islamic population is Shi'ite, one third Sunni). ${ }^{24}$ This persistence of parochialism is hardly surprising inasmuch as there has been little historical basis for national identity formation among Azeri elites, who were significantly affected by russification and are still generally lukewarm in their expressions of panTurkism. ${ }^{25}$ Perhaps the most powerful source of social cohesion and state legitimacy is the war in Nagorno-Karabakh, which has at least generated some degree of collective identity as victim of Armenian aggression ${ }^{26}$ perhaps a slender reed on which to construct a national identity conducive to developmental state building in the future.

The third group of states includes Georgia, Ukraine and Kazakhstan, each of which is characterised by a substantial degree of identity fragmentation along ethnic lines. The most extreme example is Georgia, which provides something of a cautionary tale. Here civil war has been the legacy of virulent strains of ethnic nationalism and a refusal to accommodate difference, a 
pattern which emerged under Gorbachev and continued into the post-Soviet period. Intense identity fragmentation has resulted among ethnic Georgians, Abkhaz and Ossetians, each now residing within separate territorial enclaves. ${ }^{27}$ This unfortunate outcome has been shaped by conscious strategies pursued by elites as well as by the nature of public institutions created to meet political demands.

A similar geographic patchwork quilt of identity formation can be observed in Ukraine, although with relatively greater mutual tolerance. From an ethnic perspective Ukraine includes some 21 million Ukrainophone Ukrainians, 17 million Russophone Ukrainians, and 11 million Russians. ${ }^{28}$ These ethnic and linguistic categories generally correspond to distinct discourses of ethnic identity, including Ukrainophile, pan-Slavic and Russophile. ${ }^{29}$ Here the absence of ethnic war owes largely to astute leadership and the existence of political institutions capable of giving voice to opposing demands, thus providing a context in which working compromises can tentatively be reached. ${ }^{30}$ Yet the result has been a continued absence of an overarching national identity, aside from that which is officially proclaimed. Early efforts to impose a unifying 'national idea' from the top down by western Ukrainian decision-making and intellectual elites had clearly failed by 1994 . It proved impossible to generate broad support for a national self-image as culturally and historically unique, based on an inclusivist civic conception, while at the same time mollifying pan-Slavic, Russophile and neo-Soviet identity holders. ${ }^{31}$

Kazakhstan also offers an essentially comparable picture. While numerous smaller groups are scattered throughout the country, by far the largest nationalities are Kazakhs and Russians, the latter of which totals nearly 30 per cent of the population and is concentrated in the north. While the Russian diaspora remains highly problematic, it has not resulted in overt conflict or led to a stark polarisation of identities between Kazakhs and Russians in general. ${ }^{32}$ This outcome can be traced to a prevailing official discourse that seeks to reconcile parallel identity projects. On the one hand, Nazarbaev's regime has worked hard to construct a national identity for the titular group through the familiar pattern of promoting the indigenous language and creating or reinventing national histories, cultural narratives and symbols in order to counter alternative identities of clan, tribe and region. While the delegation of this process to substate actors and their subsequent struggle for resources has actually led to some renewal of tribal identifications, Nazarbaev has succeeded in promoting a self-image of Kazakhstan as a Eurasian bridge. ${ }^{33}$ On the other hand, Nazarbaev has been able to balance ethnic and civic variants of nation building, simultaneously championing the ideals of cultural traditionalism and republican multinationalism. He also allotted Russian an important role as the language of 'interethnic communication'. His success in these efforts is attributable in part to strategy and in part to his own leadership skill. ${ }^{34}$ 


\section{Others in national identity}

The construction of Others in Eurasia has taken place through intertwined processes which Graham Smith has called essentialisation, historicisation, and 'totalisation' or the use of absolute categories. ${ }^{35}$ Here the use of dispositionally hostile and extreme imagery reproduces a situation of irreconcilable differences, which have proven extremely resistant to outside mediation. Essentialisation and totalisation have also tended to occur along ethnic lines. Such exaggerated and virulent myths of the Other are evident in Armenian and Azerbaijanian constructions of each other related to NagornoKarabakh ${ }^{36}$ or in Georgia between ethnic Georgians and South Ossetians. ${ }^{37}$

Historicisation can be seen, for example, in the tendency of cultural elites in Russia and western Ukraine to construct myths of national inception and development which are consistent with their preferred mutual relations. For western Ukrainians this means asserting the existence of an 'original' Ukrainian state as well as the depiction of later Russian domination, while Russians have tended to stress traditional cultural commonalities between the two communities. ${ }^{38}$ Consequently, although western Ukrainian elites often strategically employ the rhetoric of Slavic brotherhood for Moscow's consumption and to include Russophiles in the east, the everyday discourse in this part of the country delineates Russian imperialists (and alien Asians) as incompatible Others. ${ }^{39}$ In Russia, the discourse of national identity reproduction overwhelmingly includes the explicit identification of hostile Others abroad, such as Islamic fundamentalists and organised criminal gangs. ${ }^{40}$ This increasingly includes anti-Americanism as well, since frustration over Russia's inability to achieve claims to geopolitical influence in Eurasia and to resurgent great power status are connected with an image of America as arrogant and imperialist. ${ }^{41}$ Elsewhere, deep historical expressions of enmity towards Turkey figure prominently in Armenian identity narratives, which as already mentioned centre on a self-image of suffering and grief inflicted at the hands of the Turks. ${ }^{42}$ Without belabouring the point further, such constructions of the Other are fundamental aspects of the overall identity formations prevailing in all of the Eurasian states.

Not surprisingly, Russia itself is the most important Other for all the remaining Eurasian states, with an unenviable image ranging from imperialist aggressor (as core of the Soviet Union) to cunning wielder of influence. For Armenia, Russia embodies a melange of identity traits including Christian Orthodox, enemy of Islam, and regional hegemon. Such identification provides the basis for military cooperation, especially vis-à-vis NagornoKarabakh. In Kazakhstan, Russia is widely viewed in starkly different terms among the Russian ethnic and non-Russian ethnic populations, as Slavic defender and potentially (but not dispositionally) threatening hegemon. The latter image figures prominently in official discourse and is used to rationalise a policy of close institutional networking and sensitivity to Russian 
security concerns. The ethnicised variant of nationalist discourse in Moldova treats Russia in far more nefarious terms as historical antagonist to Moldovan self-assertion. Whether constructed as benign or hostile, however, the Russian Other invariably looms over Eurasian elites as a vast presence, central to the reproduction of national identity. ${ }^{43}$

An important additional set of Others is transnational Islam and its regional state representatives, especially Afghanistan and Iran as well as the breakaway Russian region of Chechnya. For Azerbaijan, Turkmenistan and Kazakhstan, Islam is an important constitutive feature of national identity as well as an external force. For each also, Islam is constructed primarily in ethnic and secular terms, and is therefore made compatible with the parallel civic national discourse. Azerbaijan under Aliev, like Turkmenistan and Kazakhstan, has turned to Islam mainly for appropriation as an instrument of state building. ${ }^{44}$ Thus, like the remaining Central Asian states, they joined the Economic Cooperation Organisation and Islamic Confederation Organisation soon after the fall of the Soviet Union. ${ }^{45}$ And yet Islam has also been tempered somewhat variously by Turkmenistan and Kazakhstan. Martha Brill Olcott observes that Turkmenistan has a larger devout population and has therefore pursued closer political and economic ties with the Islamic states of the Middle East than has Kazakhstan, which, given its image of Russia as potentially hostile, is committed to maintaining balanced relations with Moscow. ${ }^{46}$ This has naturally influenced the nature of the imagery as well as the extent to which Islamic themes are included in national identity formation. Still, all three states share a deep concern over the prospect of fundamentalist unrest, which could undermine the dominant identity discourse and the state's social foundation.

In contrast Armenia and Russia, both of which border predominantly Islamic countries, share an image of an Islamic radicalism. This hostile Islamic Other has been linked closely to the process of identity formation in each state, producing constructs of the nation as Christian and 'Defender of Europe'. In Armenia one important identity narrative concerns historical conflicts with Ottoman foes; indeed the Nagorno-Karabakh conflict is frequently depicted as the latest in a long series of historical battles with 'the Turks'. A similar observation applies to a lesser extent in Russia as well. Nevertheless, especially within Russian political discourse, this demonic imagery is rivalled by competing narratives of Islam. Many Russian commentaries distinguish between aggressive and peaceful variants of Islam, reflecting the fact that roughly twenty million citizens profess Islam as their religion. 47

In addition to negatively constructed Others, many Eurasian identity narratives include an array of potentially benignant Others in international society. Thus, for example, Turkey has played a key role in influencing Azerbaijan's post-Soviet identity formation and in providing more concrete forms of cooperation as well. ${ }^{48}$ By far the most salient Other, however, is the 
West and in particular the United States (although there is a salient strain of ambivalence towards America as well). Elites in all of the states of western Eurasia have sought to cultivate a 'European' identity in a broad cultural sense. This cultivation of a European identity serves domestic legitimating goals, in part by helping regimes distance themselves from the Soviet past. It has also been useful for gaining acceptance as members of the fraternity of 'advanced' states. ${ }^{49}$ For some elites, normative gravitation towards the West is a way of demonstrating the political affinity needed to obtain military and economic assistance. This orientation is true in Ukraine, Georgia and Azerbaijan, where Russian imperial images are rife and where leadership elites have at times sought American security guarantees and even lobbied for admission to NATO. Yet identification with the West is more than merely instrumental. Western economic and political practices are often described as inherently positive and are typically equated with 'civilised' ways. Thus, across Eurasia national identity formation clearly includes not only nativist but also cosmopolitan features.

\section{State capacity}

In addition to analysing the way in which national identity determines the direction of foreign policy, it is necessary to consider state strength (or weakness). State capacity directly bears on the viability of state-brokered international institutions. It is useful to follow Michael Mann's conceptualisation of 'infrastructural power' as 'the capacity of the state to actually penetrate civil society, and to implement logistically political decisions'. ${ }^{50}$ State weakness, then, in addition to meaning simply the absence of infrastructural power, involves a condition in which non-state elites retain their own cross-cutting segments of social control and may even operate through nominal state institutions. ${ }^{51}$ The term also implies an absence of coordinated monitoring and policing mechanisms for managing diffuse security threats. ${ }^{52}$ While institutional coherence and control over resources are thus important determinants of state capacity, so too is the existence of a prevailing and well-institutionalised national identity. The state's ability to promote - and link itself with - a consolidated national identity is vital to its exercise of authority.

The clear outlier with respect to state capacity in Eurasia is Turkmenistan, with its highly authoritarian and frequently coercive regime. While similar charges are sometimes levelled against the Aliev and Nazarbaev regimes in Azerbaijan and Kazakhstan, respectively, the latter do allow considerable room for dissenting opinion and independent civil society organisation. Indeed, on this score even Belarus appears relatively liberal in comparison with Turkmenistan. In any case the exercise of coercion and manipulation of fear in Turkmenistan makes it difficult to evaluate apparent state strength in some areas, such as the depth of consensus on core political 
matters. Yet the Niyazov regime does not seem to have a great deal of overall infrastructural strength regarding implementation or the ability to realise stated goals, owing largely to the fact that it remains so woefully poor that its physical and institutional capacity is limited.

The other states provide easier objects for interpretation. In Armenia the corollary of a unified national identity is indeed a strong state, one able to achieve popular mobilisation and implementation of central directives. This outcome is especially striking given the fact that state-building elites in Armenia faced the same problems of internal fragmentation that elites in Georgia and Azerbaijan did. While the resulting embattled identity has impeded development, most dramatically in blocking consideration of a 'peace pipeline' carrying Caspian oil from Azerbaijan, the state has succeeded in stabilising itself through close association with ethnic nationalist goals in Nagorno-Karabakh. ${ }^{53}$

Elsewhere, states experiencing at least substantial identity contestation do appear to have compromised state strength as a result. In Russia, for example, Putin's preferred means of accomplishing his state-building goals involves the introduction of fairly authoritarian practices, including centralisation of political authority, establishing direct ties with the regions, and putting pressure on the independent press. ${ }^{54}$ These measures are intended to repair a condition of marked state weakness which has existed since 1991, in which central institutions have been repeatedly challenged by local organs and 'oligarchs', and have generally lacked extractive and enforcement capacity. ${ }^{55}$ This picture appears to be changing, however, as Putin's emergence signals an effort to rebuild and strengthen the nation-state by invigorating a pragmatic statist discourse. Yet state weakness clearly remains a problem in autonomous ethnic republics, particularly in the Caucasus, where a jumbled assortment of unstable regions is either in the midst or on the verge of civil war. ${ }^{56}$

Similarly in Azerbaijan the state, highly personalised in the figure of Heydar Aliev, is extensively associated with official representations of national identity, such as showy parades and folk festivals. This strategy is part of an evident bid to enhance state legitimacy and authority. Nevertheless, the centre remains limited in its ability to coordinate and respond quickly to developments in the periphery. ${ }^{57}$ Much the same might be said of Kazakhstan, where Nazarbaev has gone to great lengths to present the state as the very embodiment of national identity. Yet here too, in Almaty and especially in the Russian ethnic regions of the north, the centre struggles to achieve its developmental and organisational goals.

Georgia, finally, appears to be fast approaching the extreme of failed statehood. At the time of writing, the Shevardnadze regime had lost control over Abkhazia, Ajaria and much of South Ossetia, faced potentially major opposition in Javakhetia and Mingrelia, and was under siege in Tbilisi itself. Moreover, a massive Russian troop presence along the Abkhazian frontier 
and in several military bases underlined the ineffectual nature of the regime's domestic and foreign policies. In this context even to speak of a prevailing 'Georgian' identity is something of a misnomer. Instead, such references pertain to ideas held by those within the central heartlands around the capital. Certainly, the holders of such an identity are limited in their ability to contribute to any hypothetical Eurasian security institutions.

\section{Conclusion: implications for institution building in Eurasia}

Of course, the process of nation building is relevant not only for state building but also for establishing international institutions. The viability of such institutions is determined not only by their design or abstract functional capacity, but also by the degree to which the purposes they serve conform to the identities of their members. ${ }^{58}$

For example, exploring identity formation helps explain the operational tendency in Russia to conceptualise the 'near abroad' as its exclusive sphere of influence. The prevailing tendencies in discourse have expressed the selfimage of an embattled great power surrounded by hostile or opportunistic Others. Accordingly, Russian approaches to the CIS generally incorporated assumptions of Russocentric control as well as a blurring of economic and security spheres.

In return, shared images of the Russian imperialist Other were instrumental in leading most states to reject this Russian approach and to resist joining, or fully participating in, the CIS structure. ${ }^{59}$ Instead, informed by their Eurasian or European self-understandings and Other-images, they moved to join the EU-backed Transport Corridor Europe Caucasus Asia (TRACECA) plan for energy integration in order to by-pass Russia, despite the fact that on strictly pragmatic grounds such a notion was largely illusory. ${ }^{60}$ Similarly, the combination of imperial understandings of Russia and self-understandings as European countries on the part of Georgia, Ukraine, Azerbaijan and Moldova facilitated the creation of GUAM, an economic and political association which has made overtures to the West. Even prior to GUAM, the reproduction of a European identity has played an important role in Ukraine's dealings with the West. ${ }^{61}$ In the security sphere, this has included early entry into NATO's PfP Programme and obtaining western guarantees in return for joining the Non-Proliferation Treaty and eliminating its nuclear weapons; in the economic sphere, it has meant a Partnership and Cooperation Agreement with the EU as well as the provision of American development aid. ${ }^{62}$ At the other extreme is Turkmenistan, which has steadfastly refused to join post-Soviet institutions, citing principled neutrality.

An exception is Kazakhstan, which under Nazarbaev has pursued an institutional membership policy that mirrors its complex identity discourse. As discussed above, Nazarbaev has pursued a skilful balancing act of 
promoting national identity on Kazakh ethnic lines while also embracing civic identity themes designed to assuage the fears of Russian ethnics and their protectors in Moscow. This wish to propitiate Russia and China, while still cultivating western investment, has resulted in an extremely flexible, if not protean, foreign policy. As one element of this overall balancing strategy, Nazarbaev has consistently pushed for a formal institutionalisation of Kazakhstan's interdependence with Russia. Not only did he support Mikhail Gorbachev's All Union Treaty concept, but after the fall of the Soviet Union he championed the formation of a 'Eurasian Union', which would resurrect some degree of trade integration and which prefigured the formation in 2000 of a Eurasian Economic Union (EEU) (along with Belarus, Kyrgyzstan and Tajikistan). ${ }^{63}$ This notion of Eurasianism, however, has always had broader implications as well, including bringing together East and West through traditional trade routes and perhaps offering a vehicle for bridging and even reconciling their different sociopolitical systems. ${ }^{64}$

How much analytical purchase do we get, ultimately, through such an understanding of national identity formation? One valid response would be that it provides a partial corrective to approaches that would attribute the foreign policy conduct of Eurasian states to organisational and/or material conditions alone. Assuming that current constructs are not displaced by globalisation, a crucial factor will be national identity. Thus, the prevailing discourse in (heartland) Georgia under Shevardnadze has revealed a markedly European identity, consistent with its foreign policy orientation. In contrast, Kazakhstan - with an essentially similar geopolitical position - has been characterised by a Eurasianist discourse, and has taken a far more balanced approach than Georgia, including a willingness to commit to regional economic and security institutions.

It bears repeating that the above observations are not equivalent to an assertion that identity formation caused such policy outcomes. Making such a case formally would require ruling out liberal structural explanations at the domestic level as well as demonstrating causal directionality (identity shapes policy rather than the reverse) through careful content analysis and process tracing. Nevertheless, the consolidation of national identities, and their institutionalisation as part of state building, is consequential for understanding the current and prospective dynamic of interstate relations in post-Soviet space.

Where does this leave us with regard to the outlook for security institutions? Of course, the obvious first answer is that it depends on the type of institutional arrangement envisioned. After all, the range of multilateral institutions extends from issue-specific and pragmatic regimes all the way to general and highly principled security communities. At the low end of the gradient, relatively limited forms of functional cooperation do not require the existence of common or collective identities (except perhaps at the most basic level, such as the shared identity of sovereign statehood). ${ }^{65}$ At the 
other end of the cooperative spectrum, however, shared identities are indispensable, especially in the security sphere. Even short of full-blown community formation, a significant degree of trust or perceived commonality would seem to be essential in order for shared security arrangements to emerge. ${ }^{66}$

The foregoing analysis of the Eurasian identity terrain suggests that there is currently no common, overarching identity among the post-Soviet successor states in Eurasia that might provide a sound basis for stable collective security institutionalisation. On the contrary, a general absence of shared identities bodes poorly for third-party-induced organisation, except perhaps among smaller groups of states which hold imperial or enemy images of Russia. Even in this case, however, a common identity foundation for cooperation may not suffice in the absence of state capacity. In Georgia and Moldova, for example, problems of state weakness have not only contributed to ethnic conflict but also impaired international peacekeeping efforts. ${ }^{67}$

The outlook for stable economic cooperation is probably not much brighter. An exception is the states of the EEU, which are either partly coidentified with Russia (Belarus) or dependent economically and militarily (Armenia and to a lesser extent Kazakhstan). Yet even here the disjunction between identity formation and institutional purpose suggests that the degree and duration of cooperative organisation may not be great. For that matter, the prospects for Eurasian involvement in international trade and investment flows remains poor, and few are strong candidates for future WTO membership besides Russia and Kazakhstan. Conditions for liberal development and interdependence are generally absent, while mercantilism is made more likely by prevailing threat perceptions and security anxieties. ${ }^{68}$ Judging from prevailing identity narratives, then, the most likely prospect is for a continuation of weakly institutionalised economic and security space throughout post-Soviet Eurasia, at least for the foreseeable future.

\section{Notes}

1 See Irina Zviagelskaia and Vitali Naumkin, 'Non-Traditional Threats, Challenges, and Risks in the Former Soviet South', in Graham Smith, Edward Allworth and Vivien Law (eds), Nation-Building in the Post-Soviet Borderlands: The Politics of National Identities (Cambridge: Cambridge University Press, 1998), pp. $226-47$.

2 Fredrik Barth, 'Introduction', in Fredrik Barth (ed.), Ethnic Groups and Boundaries: The Social Organization of Cultural Difference (Boston: Little, Brown, 1969), pp. 9-38.

3 I follow the distinction drawn by Kowert and Legro, who define norms as the 'regulative cultural content of international politics' and identities as 'regulative accounts of actors themselves'. Paul Kowert and Jeffrey Legro, 'Norms, Identity, and their Limits: A Theoretical Reprise', in Peter Katzenstein (ed.), The Culture of National Security: Norms and Identity in World Politics (New York: Columbia University Press, 1996), p. 453. 
4 A second caveat is that this chapter represents only an illustrative, and rather tentative, overview of key themes in the public discourse of post-Soviet Eurasia, based almost entirely on secondary source materials. The point here is not to characterise or delimit definitively the prevailing identity constructs in this region, but rather to provide an indicative guide to the most salient patterns of identity formation and the influences upon this process.

5 Benedict Anderson, Imagined Communities: Reflections on the Origin and Spread of Nationalism, rev. edn (New York: Verso, 1991).

6 As Brubaker argues, '[W]e should focus on nation as a category of practice, nationhood as an institutionalized cultural and political form, and nationness as a contingent event or happening, and refrain from using the analytically dubious notion of "nations" as substantial, enduring collectivities.' Rogers Brubaker, Nationalism Reframed: Nationhood and the National Question in the New Europe (Cambridge: Cambridge University Press, 1996), p. 21.

7 On identity formation and the construction of Others, see Alexander Wendt, Social Theory of International Politics (Cambridge: Cambridge University Press, 1999), pp. 326-35. For Wendt, borrowing from symbolic interactionism, identity formation in international politics is relational and evolves through contact with Others. In contrast, other scholars emphasise the importance of pre-existing understandings or ontologically distinct developments concerning self-Other identification at home. See Naeem Inayatullah and David Blaney, 'Knowing Encounters: Beyond Parochialism in International Relations History', in Yosef Lapid and Friedrich Kratochwil (eds), The Return of Culture and Identity in IR Theory (Boulder, CO: Lynne Rienner, 1996), pp. 65-84; also Ted Hopf, Social Construction of International Politics: Identities and Foreign Policies, Moscow, 1955 and 1999 (Ithaca, NY: Cornell University Press, 2002 ).

8 As David Campbell observes, 'the state more often than not precedes the nation: ... nationalism is a construct of the state in pursuit of its legitimacy'. David Campbell, Writing Security: United States Foreign Policy and the Politics of Identity, rev. edn (Minneapolis: University of Minnesota Press, 1998), p. 11.

9 For example, leaders of states whose identity was constructed around the norm of pan-Arab solidarity were constrained to promote policies at odds with their insular preferences. See Michael Barnett, 'Sovereignty, Nationalism, and Regional Order in the Arab State System', International Organization, 49:3 (1995), pp. 479-510. See also Martha Finnemore and Kathyrn Sikkink, 'International Norm Dynamics and Political Change', International Organization, 52:4 (1998), pp. 887-917.

10 Phillip Roeder, 'Soviet Federalism and Ethnic Mobilization', World Politics, 43:2 (1991), pp. 196-232; Ronald Suny, The Revenge of the Past: Nationalism, Revolution, and the Collapse of the Soviet Union (Stanford, CA: Stanford University Press, 1993).

11 For example, see the following chapters in Smith et al., Nation-Building: Andrew Wilson, 'National History and National Identity in Ukraine and Belarus', pp. 23-47; Viktor Shnirelman, 'National Identity and Myths of Ethnogenesis in Transcaucasia', pp. 48-66, and Edward Allworth, 'History and Group Identity in Central Asia', pp. 67-90.

12 Svante Cornell, Small Nations and Great Powers: A Study of Ethnopolitical Conflict in the Caucasus (Richmond: Curzon Press, 2001); Alexander Agadjanian, 'Revising 
Pandora's Gifts: Religious and National Indentity in the Post-Soviet Societal Fabric', Europe-Asia Studies, 53:3 (2001), pp. 473-89.

13 Olivier Roy notes a 'growing contradiction between the juridical framework of the new constitutions, which privilege the concept of citizenship, and the real practices of the countries concerned, which emphasize ethnicity'. Olivier Roy, The New Central Asia: The Creation of Nations (New York: New York University Press, 2000), p. 175. See also Graham Smith, 'Post Colonialism and Borderland Identities', in Smith, et al., Nation-Building, pp. 1-20. Although Russian discourse often demonises Chechens and swarthy Caucasians in general, even here the overall thrust of the dominant discourse embraces civic nationalism. See Valery Tishkov, Ethnicity, Nationalism and Conflict in and after the Soviet Union: The Mind Aflame (London: Sage, 1997), esp. pp. 259-71.

14 Ronald Suny, 'Provisional Stabilities: The Politics of Identities in Post-Soviet Eurasia', International Security, 24:3 (1999/2000), pp. 139-79; and Brubaker, Nationalism Reframed.

15 Shahram Akbarzededeh, 'National Identity and Political Legitimacy in Turkmenistan', National Papers, 27:2 (1999), pp. 271-90.

16 Leading examples are Hopf, Social Construction; Vera Tolz, 'Forging the Nation: National Identity and Nation Building in Post-Communist Russia', Europe-Asia Studies, 50:6 (1998), pp. 993-1022; and Astrid Tuminez, Russian Nationalism since 1856: Ideology and the Making of Foreign Policy (Lanham, MD: Rowman and Littlefield, 2000).

17 A contemporary example is Aleksandr Neklessa, who asserts that Russia is inherently opposed to the spread of 'Western European civilisation' and carries within itself an alternative, Orthodox basis for re-establishing global community. Aleksandr Neklessa, 'Konets tsivilizatsii, ili zigzag istorii', Znamia, 1:3 (1998), pp. 165-79. See also Timo Piirainen, 'The Fall of an Empire, the Birth of a Nation: Perceptions of the New Russian National Identity', in Chris Chulos and Timo Piirainen (eds), The Fall of an Empire, the Birth of a Nation: National Identities in Russia (Burlington, VT: Ashgate, 2000), pp. 161-96. On the increasing role of Orthodoxy see Agadjanian, 'Revising Pandora's Gifts'. For an historical perspective see Tim McDaniel, The Agony of the Russian Idea (Princeton, NJ: Princeton University Press, 1996), pp. 22-55; and Nikolas Gvosdev, 'The New Party Card? Orthodoxy and the Search for Post-Soviet Russian Identity', Problems of PostCommunism, 47:6 (2000), pp. 29-38.

18 For example, Aleksei Arbatov, Rossiiskaia natsionalnaia ideia i vneshniaia politika (Moscow: Moscow Social Science Foundation, 1998), pp. 6-18; see also Hopf, Social Construction.

19 Aleksandr Dugin, despite his hardline expansionist predilections, remains influential as an 'expert' on geopolitical matters. For a discussion, see Ilan Berman, 'Slouching Toward Eurasia?', Perspective, 12:1 (2001), on-line at www.bu.edu/iscip/. Zevelev suggests that this developed as part of the narrative of the New Soviet Man, which mobilised Russian nationalism by instituting a de facto russification of language and culture. Igor Zevelev, 'The Russian Quest for a National Identity: Implications for Security in Eurasia', in Sharyl Cross et al. (eds), Global Security Beyond the Millennium: American and Russian Perspectives (New York: St Martin's Press, 1999), pp. 110-30.

20 Algimantas Prazauskas, 'The Influence of Ethnicity on the Foreign Policies of the 
Western Littoral States', in Roman Szporluk (ed.), National Identity and Ethnicity in Russia and the New States of Eurasia (New York: M. E. Sharpe, 1994), pp. 150-84; Jeff Chinn, 'Moldovans: Searching for Identity', Problems of PostCommunism, 44:3 (1997), pp. 43-52; William Crowther, 'Moldova: Caught Between Nation and Empire', in Ian Bremmer and Ray Taras (eds), New States, New Politics: Building the Post-Soviet Nations (Cambridge: Cambridge University Press, 1997), pp. 316-49.

21 Sherman W. Garnett and Rachel Lebenson, 'Ukraine Joins the Fray', Problems of Post-Communism, 45:6 (1998), pp. 22-33; and Ted Gurr and Michael Haxton, 'The Gagauz of Moldova: Settling an Ethnonational Rebellion', in Ted Gurr (ed.), Peoples Versus States: Minorities at Risk in the New Century (Washington, DC: United States Institute of Peace, 2000), pp. 140-63.

22 Nevertheless, even in Transdniestria the pattern of political opportunism and conflict has crystallised into embedded institutions which have so far stymied all efforts at resolution. Stuart Kaufman, 'Spiraling to Ethnic War: Elites, Masses and Moscow in Moldova's Civil War', International Security, 21:2 (1996), pp. 108-38.

23 Elin Suleymanov, 'Azerbaijan, Azerbaijanis and the Search for Identity', Analysis of Current Events, 13:1 (2001), pp. 3-6.

24 Mehran Kamrava, 'State-Building in Azerbaijan: The Search for Consolidation', Middle East Journal, 55:2 (2001), pp. 216-37; Audrey Altstadt, 'Azerbaijan's Struggle Toward Democracy', in Karen Dawisha and Bruce Parrott (eds), Conflict, Cleavage, and Change in Central Asia and the Caucasus (Cambridge: Cambridge University Press, 1997), pp. 110-55; and Tadeusz Swietochowski, 'Azerbaijan: Perspectives from the Crossroads', Central Asian Survey, 18:4 (1999), pp. 419-35.

25 Suny, 'Provisional Stabilities'; and Swietochowski, 'Azerbaijan'.

26 Cornell, Small Nations and Great Powers, pp. 78-125.

27 George Hewitt, 'Abkhazia, Georgia and the Circassians (NW Caucasus)', Central Asian Survey, 18:4 (1999), pp. 463-500.

28 Andrew Wilson, 'Redefining Ethnic and Linguistic Boundaries in Ukraine: Indigenes, Settlers, and Russophone Ukrainians', in Smith et al. Nation-Building, pp. 119-38.

29 Wilson, 'National History', pp. 23-47.

30 Alexander Motyl and Bohdan Krawchenko, 'Ukraine: From Empire to Statehood', in Bremmer and Taras, New States, New Politics, pp. 235-75.

31 Victor Stepanenko and Sergei Sorokopud, 'The Construction of National Identity: A Case Study of the Ukraine', in Christopher Williams and Thanasis Sfikas (eds), Ethnicity and Nationalism in Russia, the CIS and the Baltic States (Brookfield, VT: Ashgate, 1999), pp. 184-210; see also Taras Kuzio (ed.), Contemporary Ukraine: Dynamics of Post-Soviet Transformation (Armonk, NY, and London: M. E. Sharpe, 1998).

32 Emil Pain, 'Contagious Ethnic Conflicts and Border Disputes along Russia's Southern Flank', in Smith et al., Nation-Building, pp. 177-202. Martha Olcott notes the existence of domestic policy constraints upon Nazarbaev owing to the combination of divergent ethnic identities and resource distributions, and therefore possible social tensions. See Olcott, 'Nation Building and Ethnicity', in Szporluk, National Identity, p. 225.

33 On the salience of Kazakh ethnicity over competing identities and the basic cleav- 
age between Kazakh and Russian ethnicities in national identity, see Pal Kolsto, 'Bipolar Societies?', in Pal Kolsto (ed.), Nation-Building and Ethnic Integration in Post-Soviet Societies (Boulder, CO: Westview Press, 1999), pp. 15-43. On multiple identities in Kazakhstan, see also Martha Olcott, 'National Consolidation', Harvard International Review, 22:1 (2000), pp. 50-5; on unintended tribal identity effects, see Edward Schatz, 'The Politics of Multiple Identities: Lineage and Ethnicity in Kazakhstan', Europe-Asia Studies, 52:3 (2000), pp. 489-506.

34 Jorn Holm-Hansen, 'Political Integration in Kazakhstan', in Kolsto, Nation-Building and Ethnic Integration, pp. 153-226; and Azamat Sarsembayev, 'Imagined Communities: Kazak Nationalism and Kazakification in the 1990s', Central Asian Survey, 18:3 (1999), pp. 319-47. Martha Olcott points out that Kazakhstan is the only Central Asian state that neither officially celebrates any Muslim holiday nor refers to Islam in its constitution. Olcott, 'Nation Building and Ethnicity', pp. 218-19. As Suny suggests, 'Kazakhstan's relative success in the last decade in avoiding serious violence can in large part be attributed to a leadership adept at deploying discourses and policies that blur differences and lessen tensions'. Suny, 'Provisional Stabilities', p. 154. See also Martha Olcott, 'Nursultan Nazarbaev and the Balancing Act of State Building in Kazakhstan', in Timothy Colton and Robert Tucker (eds), Patterns in Post-Soviet Leadership (Boulder, CO: Westview Press, 1995), pp. 169-90.

35 Smith, 'Post Colonialism and Borderland Identities'.

36 Nora Dudwick, 'The Cultural Construction of Political Violence in Armenia and Azerbaijan', Problems of Post-Communism, 42:4 (1995), pp. 18-20.

37 Shnirelman, 'National Identity and Myths of Ethnogenesis'.

38 Serhii Plokhy, 'The Ghosts of Pereyaslav: Russo-Ukrainian Historical Debates in the Post-Soviet Era', Europe-Asia Studies, 53:3 (2001), pp. 489-506.

39 Mikhail Molchanov, 'Post-Communist Nationalism as a Power Resource: A Russia-Ukraine Comparison', Nationalities Papers, $28: 2$ (2000), pp. 263-89; Wilson, 'National History'.

40 Suny, 'Provisional Stabilities'; on the prevalence of anti-American imagery in Russia, see Stephen Blank, 'Partners in Discord Only', Orbis, 44:4 (2000), pp. 557-71. Hopf notes that the dominant Russian self-image as a 'European' country is meant partly to express rejection of America as well as embrace of Europeanism. Hopf, Social Construction.

41 Ibid.

42 For example, see Nora Dudwick, 'Armenia: The Nation Awakes', in Ian Bremmer and Ray Taras (eds), Nations and Politics in the Soviet Successor States (Cambridge: Cambridge University Press, 1993), pp. 261-87.

43 Prazauskas, 'Influence of Ethnicity', p. 169.

44 Graham Smith, The Post-Soviet States: Mapping the Politics of Transition (New York: Oxford University Press, 1999), Ch. 4. Despite official use of Islamic symbols, the Azeri elite has been from the outset overwhelmingly secular in orientation. See Tadeusz Swietochowski, Russia and Azerbaijan: A Borderland in Transition (New York: Columbia University Press, 1995), pp. 193-220.

45 Olcott suggests that this was done in part to balance the overall policy orientation and partly for purely opportunistic reasons. Olcott, 'Nation Building and Ethnicity', p. 215.

46 Ibid. 
47 Aleksei Malashenko, 'Russian Nationalism and Islam', in Michael Waller, Bruno Coppieters and Alexei Malashenko (eds), Conflicting Loyalties and the State in Post-Soviet Eurasia (Moscow: Institute of Oriental Studies, Russian Academy of Sciences, 1998), pp. 187-202.

48 On early and deep attractions to Turkic cultural and religious forms, see Shireen Hunter, 'Azerbaijan: Search for Identity', in Bremmer and Taras, Nations and Politics, pp. 225-60.

49 On legitimation see Andrew Cortell and James Davis, 'How Do International Institutions Matter? The Domestic Impact of International Rules and Norms', International Studies Quarterly, 40:4 (1996), pp. 451-78. All the Eurasian successor states immediately turned for help and guidance to the West and to the major western-dominated international organisations. All joined the World Bank and International Monetary Fund (IMF), while Georgia and Moldova have joined the World Trade Organisation (WTO) and all others except Turkmenistan have observer status. Furthermore all joined the OSCE, and all but Kazakhstan and Turkmenistan, which are geographically ineligible, joined the Council of Europe.

50 Michael Mann, 'The Autonomous Power of the State', in Marvin Olsen and Martin Marger (eds), Power in Modern Societies (Boulder, CO: Westview Press, 1993), p. 315. Despotic power refers to the distributive power of state elites over civil society, without requiring any institutionalised negotiation. Thus the advanced capitalist democracies are 'despotically weak but infrastructurally strong'.

51 Joel Migdal, Strong Societies and Weak States: State-Society Relations and State Capabilities in the Third World (Princeton, NJ: Princeton University Press, 1988).

52 On Russian state weakness as leading to the emergence of 'mafia' groups which exert partial control over organised violence and taxation, see Vadim Volkov, 'Violent Entrepreneurship in Post-Communist Russia', Europe-Asia Studies, 51:5 (1999), pp. 741-54.

53 Suny, 'Provisional Stabilities'.

54 Sarah Mendelson, 'The Putin Path', Problems of Post-Communism, 47:5 (2000), pp. 3-12.

55 For example, see Michael McFaul, 'State Power, Constitutional Change, and the Politics of Privatization in Russia', World Politics, 47:2 (1995), pp. 210-43; and Vladimir Shlapentokh, Roman Levita, and Mikhail Loiberg, From Submission to Rebellion: The Provinces Versus the Center in Russia (Boulder, CO: Westview Press: 1997). Empirically, on the basis of extensive regional survey data, Stoner-Weiss attributes the central state's lack of authority and inability to attain policy implementation to the emergence of powerful group and regional interests which oppose the realisation of central state power. See Kathryn Stoner-Weiss, 'Wither the State? The Regional Sources of Russia's Post-Soviet Governance Crisis', paper prepared for the 2000 Annual Meeting of the American Political Science Association, Washington, DC, 31 August-3 September, 2000.

56 On Chechnya, see John Dunlop, Russia Confronts Chechnya: Roots of a Separatist Conflict (New York: Cambridge University Press, 1998); and Anatol Lieven, Chechnya: Tombstone of Russian Power (New Haven,CT: Yale University Press, 1998). On other conflicts in the Caucasus, see Cornell, Small Nations and Great Powers, pp. 197-284; Fiona Hill, Russia's Tinderbox: Conflict in the North Caucasus and its Implications for the Future of the Russian Federation (Cambridge, MA: 
Harvard University, JFK School of Government, Strengthening Democratic Institutions Project, September 1995); and Jane Omrod, 'The North Caucasus: Confederation in Conflict', in Bremmer and Taras, New States, New Politics, pp. 96-139.

57 Kamrava, 'State-Building in Azerbaijan'.

58 As Cronin observes, neo-liberal accounts of the availability of international regimes can explain the emergence of cooperation, but cannot adequately explain the range of possible institutional outcomes. Bruce Cronin, Community Under Anarchy: Transnational Identity and the Evolution of Cooperation (New York: Columbia University Press, 1999).

59 Jan Adams, 'The CIS States: Going Global', Post Soviet Prospects, 5:1 (1997), on-line at www.csis.org/ruseura/psp/pspv1.html. Also William Crowther, 'Moldova: Caught Between Nation and Empire', in Bremmer and Taras, New States, New Politics, pp. 316-49.

60 David Mark, 'Eurasia Letter: Russia and the New Transcaucasus', Foreign Policy, 105 (1996/97), pp. 141-59.

61 Henry Hale, 'Integration and Independence in the Caspian Basin', SAIS Review, 19:1 (1999), pp. 163-89.

62 Jennifer Moroney, 'Frontier Dynamics and Ukraine's Ties to the West', Problems of Post-Communism, 48:2 (2001), pp. 15-25; also Molchanov, 'Post-Communist Nationalism'.

63 Olcott, 'Nursultan Nazarbaev and the Balancing Act'.

64 This point is made by Schatz, 'Politics of Multiple Identities'.

65 Indeed, under certain conditions narrowly functional regimes may be successful despite the lack of any substantial affinity among their members. See Oran Young, International Governance: Protecting the Environment in a Stateless Society (Ithaca, NY: Cornell University Press, 1994).

66 Charles Kupchan and Clifford Kupchan, 'The Promise of Collective Security', International Security, 20:1 (1995), pp. 52-61.

67 Dov Lynch, 'Euro-Asian Conflicts and Peacekeeping Dilemmas', in Yelena Kalyuzhnova and Dov Lynch (eds), The Euro-Asian World: A Period of Transition (New York: St Martin's Press, 2000), pp. 3-27.

68 Hendrik Spruyt and Laurent Ruseckas, 'Economics and Energy in the South: Liberal Expectations Versus Likely Realities', in Rajan Menon, Yuri Fyodorov and Ghia Nodia (eds), Russia, the Caucasus, and Central Asia: The 21st Century Security Environment (Armonk, NY: M. E. Sharpe, 1999), pp. 87-118. 